\title{
Strengthening Nation's Character through Saprahan Local Wisdom as Civic Culture of Malay Sambas Society in Kalimantan Barat
}

\author{
Hemafitria Hemafitria \\ Student of Civic Education Doctoral Program \\ Universitas Pendidikan Indonesia \\ Bandung, Indonesia \\ Hemafitria@student.upi.edu
}

\author{
Dasim Budimansyah, Udin Winataputra \\ Lecturer of Civic Education Doctoral Program \\ Universitas Pendidikan Indonesia \\ Bandung, Indonesia
}

\begin{abstract}
This study is intended to identify the characters values that grow and develop in Sambas Malay subculture through local wisdom Saprahan tradition and the process of functioning the character values through Saprahan tradition as civic culture of Malay Sambas society. This study is based on the tradition phenomenon which is merely a habit activity without extracting its value and the process of functioning values into life characters. The phenomenon of social life has shown quite critical degradation even has disturbed the social-cultural order that makes the daily behavior of society deviate from the character of the nation in the Pancasila philosophy. The importance of strengthening the character's value has great contribution in managing relationships between society members to create a harmonious relationship among them. Thus, a harmonious relationship in this research is one of the final objectives of the character realization originated from the values of local wisdom. This research applied a qualitative approach with ethnography method on Sambas Malay society which covers society figures, religious figures, youth leaders, Malay traditional leaders and Sambas district government apparatus. In this study, data and information collection is done through participatory observation, open and in-depth interview, and documentation studies. Data analysis techniques include three activities that occur simultaneously: data reduction, data presentation, conclusion/verification. Research findings show that Sambas Malay society have a high concern with the activities of Saprahan tradition. The continuity of performing tradition acculturated in social life has true values of character building. The character values include the values oriented towards religious value, social value, economic value, knowledge value, art value, language value and technology value. Finally, these values are empowered in society life through various social activities and even regarded to be behavior standards. Moreover, applying the local wisdom of Saprahan tradition in Sambas Malay society can represent the formation of civic culture in society, which is expected to realize good and smart citizen in accordance with the values of Pancasila.
\end{abstract}

Keywords—civic culture; local wisdom; nation character; saprahan

\section{INTRODUCTION}

The development of nation's character historically and socio-culturally is a national commitment that has been growing and developing in the life of Indonesian society, nation and state. However, the social interaction has shown considerable degradation. This is seen from the crisis of moral values due to the globalization. The lacks of politeness, recpecting each other, sense of togetherness, mutual cooperation and tolerance among the society members lead to the daily behavior of current society deviating from the nation's characters based on Pancasila philosophy [1]. The underlying problem is identity degradation due to the collapse of the nation's character. Accordingly, nation and character building must be the core development in opening the way to civilized society [2].

The crisis of nation's character leads to critical intercultural, inter-religious relationships in social life that greatly affects the integrity of nation. Understanding mutual respect, tolerance and sense of togetherness in the life of society, nation and state has not been deeply instilled [3]. The decline of polite culture in some Malay young generations becomes the concern of Malay older generation. In addition, there are some activities againts social, cultural and religious values such as gambling, hard labor, sexual harassment and even drugs. This condition happens in some Sambas young people. According to Sambas Malay society leaders, the problems occur due to many factors: poor parental control, less or neglected values and religion education, declining role of religious leaders, critical influence of telecommunication and information and the influence of post-conflict effects in a small number of Sambas young people.

This condition may affect the social orders, especially Sambas Malay people who are well-known with being polite, and religious. Therefore, understanding and practicing the values of local wisdom become a necessary new form of education. It is supposed that an attempt to respond negative impacts through cultural communication that show modesty in Sambas Malay society and even any culture is believed to be 
an alternative solution that can deal with moral degradation leading to ethnic conflict and prevent conflicts to happen again [4].

Furthermore, local culture is one of the foundations in national character building which reflect one's behavior in society [5]. According to Permana in Alfian local wisdom is a local policy which is defined as a life view, knowledge and various life strategies in forms of activities within local societies in responding problems in meeting their needs [3]. System of economic, technology, social organization, language, communication and art fulfillment can be tradition, petitih-petitih or life slogan. Furthermore, Anggraini and Kusniarti define local wisdom as a local wealth that covers a policy or a worldview [6]. Local wisdom serves to make humans wiser in their lives.

Accordingly, it is seen to be important to conduct study on Sambas Malay society structure which has a very interesting local cultural value in the context of globalization which requires strengthening the character as the nation's personality. In this research, it is believed that strengthening the nation's character is expected to apply in everyday life of society by way of re-functioning Saprahan culture prevailing in Sambas society. The strengthening of this local value can identify the character values that grow and develop in Sambas Malay subculture through Saprahan tradition and the process of functioning the character values through Saprahan tradition as civic culture of Sambas Malay society used as practical guidance in realizing the society with the character of Pancasila values. Therefore, the modeling of local wisdom values within the framework of Sambas Malay ethnic community is very important.

\section{THEORETICAL}

Local wisdom is a local treasure that contains a policy or worldview [6]. Local wisdom serves to make humans wiser in their lives. In line with that meaning, that local wisdom means harmonious relationship between man, nature and the built environment in a region that is also influenced by its culture. Furthermore, local wisdom of Indonesian society reflect relationship between human and God, human and universe.

It is necessary to develop local potentials in building character through approaches of socialization, internalization and habituation. Fajarini states that local wisdom will only survive forever if local wisdom is implemented in everyday life so as to respond the times [7]. In order for local culture to keep up with the times and to maintain the local identity in globalization, it needs to utilize human culture. This is in line with Mallinowski's Functionalist theory that "all cultural activities are actually intended to satisfy a series of the needs of the human instincts that are related to their whole life [8]. Based on the above related view, this study applied the theory of cultural functionalism as the basis of thinking framework on Saprahan culture in Sambas to be able to function in public life in the development of civic culture in shaping character.

In order for local culture to keep up with the times and to maintain the local identity in globalization, it needs to utilize human culture. This is in line with Mallinowski's Functionalist theory that "all cultural activities are actually intended to satisfy a series of the needs of the human instincts that are related to their whole life [8]. Based on the above related view, this study applied the theory of cultural functionalism as the basis of thinking framework on Saprahan culture in Sambas to be able to function in public life in the development of civic culture in shaping character.

The habituationof character building and people's character is inevitably separated from the civic culture. Every member of society must maintain civic culture. It is hoped that these noble values continue to exist and are performed in everyday life, so that society's identity can be visible, as Winataputra and Budimansyah stated that identified the civic culture as a culture sustaining citizenship that contains a set of ideas that can be effectively realized in cultural representation for establishing citizen identities [9]. Some elements of civic culture cover civic virtues or citizenship virtues that embraces the citizens active involvement, alignment/egalitarian, mutual trust and tolerance, cooperative life, solidarity and social spirit [10]. In line with this Annette states" Within the circuit of civic cultures, ideas of popular spaces, practices, and identities are significant to critical analysis of social and cultural participation [11]." In a series of civic cultures there are significant space of ideas, practices, and significant identity for critical analysis of social and cultural participation.

The discussion above implies that the nation of Indonesian must have a national identity which is stated in Pancasila, saying that every Indonesian citizen must civilize Pancasila. In this way all Indonesian citizens know their lives guidelines as citizens of Indonesia in accordance with the concept of their respective cultures based on Pancasila democracy.

\section{METHOD}

This study applied a qualitative approach with ethnographic method in Malay Sambas society. Ethnography method is aimed at describing in detail the cultural phenomenon of Malay Sambas society that can be obtained from the naturally research participation. Spradley states that ethnography is a work of describing a culture [12]. The main objective of the activity is understanding a life view from the indigenous population's point of view, related to life in gaining a view of their world. Thus, ethnographic method is an attempt to describe a culture to obtain an overview of the research subject. The research subject is a number of cultural groups to be described and analyzed regarding their behavior, beliefs, language and the way they develop a common interaction pattern over times. Meanwhile, the subject of this research is Malay Sambas society.

In this study, data collection technique is known as field notes, which cover three techniques used in the process of collecting data, ie participant observation, in-depth interview, and documentation. Data presentation and analysis are done in all series of field research activities since the beginning of study until its ending. While data analysis techniques comprises three activities that occur simultaneously namely: data reduction, data presentation, conclusion/verification [13]. Qualitative data analysis is an ongoing, repetitive and continuous effort. The phases of data reduction, data presentation, and conclusion are the sequences of analysis. 


\section{RESULT AND DISCUSSION}

Saprahan tradition is the custom of Sambas Malay society that covers enjoying the food served by forming a circle and sitting cross-legged. It is served in the following occasions like wedding, tepung tawar, sya'banan and others where the meal is usually consumed by six people. In other words, eating tradition of Saprahan can be defined briefly as sitting with legs folded in front of tray (duduk bersila nampa), namely to eat together before a large tray with a variety of side dishes.

There are some components of Saprahan tradition as follows, first: one Bareng of rice symbolizing that the source of life is the One Allah who has given life and blessing to humans that they must be grateful. Second, 2 (two) tablespoons for side dishes symbolizes two sentences of shahadah as the key of human faith. Third, 5 types of side dishes as a symbol of the pillars of Islam that Muslim must implement in their life. Fourth, the necessi ty of 6 (six) people gathering in Sesaprah as a symbol of the pillars of faith that should not be faraway from everyday human lifetime. Fifth, the necessity of a small container of clean water to wash hands.

Based on the description above, it is concluded that Saprahan tradition is the custom of Sambas Malay society that has full meaning in terms of enjoying many types of food such as five or more Pekare together with sitting cross-legged on the floor in a circle or lined up in a small groups surrounding the food eaten with hand by six people. This means that Saprahan eating has valuable benefit. The benefit is reflected in the blessing that God has given to us which can make better human, more obedient, and thankful. Saprahan has not only an world life orientation but also Hereafter orientation.

\section{A. Character Values that Grow in Sambas Malay Subculture Through the Local Wisdom of Saprahan Tradition}

The wisdom values within Saprahan tradition comprise religious value in term of blessing that has been given in human life which must be appreciated, friendship values as reflection of behaviors by always maintaining a good relationship with positive interaction among people in a society, social concern that shows sensitivity to all problems in the environment and society which control the desire not to dominate something for-the general virtue, the hospitality value during communication when Saprahan tradition takes place as an effort to encourage others to make interaction and the courtesy value such as dress ethics, sitting ethics on the Tarup. In other words, Saprahan tradition of Sambas Malay community has a lot of local wisdom and religious values. Local wisdom as knowledge based on the experiences of people that is handed down over the generations [14]. Local wisdom is the culture that is transmitted or inherited from one generation to the next, has been proved its superiority, known as local wisdom. Therefore, local knowledge is a part of their wise way of life in order to solve all the life problems, develop and maintain their life sustainably.

The local wisdom values when implemented in social life can be a reference in seeing and determining the characters of a society. Saprahan tradition with its noble sociol-cultural and religious values can be taken up a source of innovation and skills that can empower the welfare of Sambas Malay society and even multi-ethnic communities in Sambas.

The wisdom values originating from Saprahan tradition can be strengthened and modified through civil education that involves the leaders of religion and custom. Saprahan tradition in Malay Sambas society comprises the elements of language, knowledge system, social organization, religious system, and arts too. The language element is seen in local languages practice of Sambas Malay society. Meanwhile the system of knowledge element is seen during the tradition ceremony in which everyone is demanded to understand some points such as dress code, sitting position, eating procedures in order that he is not labelled to be impolite. Moreover, the organizational element is seen when all people involved have their own roles and responsibilities at least to succeed Saprahan tradition event. Saprahan tradition has religious element because Saprahan tradition always begins and ends with a prayer in addition to a compliment to the noble Prophet Muhammad. According to Rashid in Malay society, the characteristics of Islam become the principle behaviors, actions, forms and relationships, the essence of values, attitudes, and the Islamic teachings have become the soul of overall social and cultural life in Malay society implying the norms of conducts and association [15]. Finally, the tradition has the art element because Saprahan tradition especially in the wedding party before having meal usually has reciting zikiran, Nyalai or Sarafalan that contains praise to the noble Prophet with a harmonious rhythm and tone followed by the traditional musical instruments.

\section{B. Process of Character Values Functioning Through Besaprah Tradition as a Civic Culture}

The characters values originated from the local wisdom of Saprahan tradition seems to be very rational if these values can be empowered or functioned to be the identity of society. In response to the cases occurring in Sambas society, the researchers applied Talcott Parsons perspective on structural differentiation theory and social change that the character shift must be seen as a change of social system in Sambas Malay society. The differentiation process, various functions in a system form separate structural units. These structures are mutually supportive and tend to lead to dynamic balance. Accordingly, Parsons says that the social changes occurring in traditional societies can be measured not only from changing social structures, but also from the changes in the individual or social actions [16].

In order for the social system not to change, it must be regulated. As for this study, the regularity and survival of the social system of Saprahan tradition are concerned to be processed into civic culture with some steps. The steps cover adaptation as an effort of acceptance for all parties to the value originated from Saprahan tradition, goal achievement in making peace for a harmonious order in society, integration as an effort to equate the perception by showing the advantages or benefits for togetherness, patterns maintenance to make sure that Saprahan character traits exist in society. All these steps are interconnected through involving all well-functioning social systems. 
The research findings show that the character values with their advantages and benefits in Saprahan tradition of Sambas Malay society become the culture of society. This is based on the Winataputra framework on the elements of civic culture in civic virtue or civic morality that includes people's active participation, equality/egalitarian relationship, mutual trust and tolerance, cooperative life, solidarity and civic spirit [10]. Therefore, Saprahan tradition with the values of character in the religious values is seen in gratitude expression; respecting guest and respecting host as an attitude of not underestimating others; and sense of belonging to family and hometown, Jerampah is a manifestation of concern value, society active involvement and good cooperation, not showing individual behavior. The tradition teaches people how to maintain the social nature through communication during Saprahan tradition that take place in celebration, and not to make a monopoly in communication and Saprahan dishes as a manifestation of tolerance and egalitarianism.

Sambas Malay society that adopts religion and custom as action benchmark are regarded to be a picture of good citizens in the sight of custom and religion. As for cultural citizenship, Sambas Malay community already has a pattern in implementing the process of citizen identity through local wisdom Saprahan tradition. Therefore, the steps of adaptation, goal achievement, and integration in functioning character value of Saprahan tradition as civic culture require step that can maintain pattern or consistency. Through community civics, the formation of good Indonesian citizens that have knowledge, attitudes, values and skills is related to the implementation of the citizens' right and obligation in the national and state life based on the ideology of Pancasila.

\section{CONCLUSION}

In fact, the local wisdom of Saprahan tradition in Sambas Malay society has a lot of character values. The values comprise religious, social and cultural values which should turns a culture of citizenship that can be functioned strategically through adaptation, goal achievement, integration and maintenance of the pattern. Therefore, civic community education becomes one of the efforts in strengthening the character of nation truly implemented with a distinctive style. Thus, the character values originated from the local wisdom of Saprahan tradition becomes an inspiration and innovation concerning the civic cultural content through socio-cultural interaction in the life of community, nation and state which provides the contribution in civic education "by considering the value of Pancasila in order to strengthen the character of nation to be the identity of good and intelligent citizens.

\section{REFERENCES}

[1] N. Zuriah, "Kajian Etnopedagogi Pendidikan Kewarganegaraan sebagai Wahana Pendidikan Budaya dan Karakter Bangsa di Perguruan Tinggi Muhammadiyah Kota Malang," Jurnal Humanity, vol. 8, No. 1, pp. 170 - 185, September 2012.

[2] Fauzi, "Kearifan Lokal Untuk Membangun Karakter Bangsa", ArRaniry International Journal of Islamic Studies vol. 1, No.1, Juni 2014.

[3] M. Alfian, "Potensi Kearifan Lokal dalam Pembentukan Jati Diri dan Karakter Bangsa," Prosiding The 5th International Conference on Indonesian Studies, "Ethnicity and Globalization" di Jogyakarta, Juli 2013.

[4] Wahab, "Sapa And Base Communication Of Sambas Society: A Case Of Malay-Madurese Post-Conflict 1999-2014," International Journal Of Scientific \& Technology Research, vol. 4, No. 02, February 2015.

[5] R. Yunus, "Transformasi nilai-nilai budaya lokal sebagai upaya pembangunan karakter bangsa," Jurnal Penelitian Pendidikan, vol. 13, 2013.

[6] P. Anggraini, dan T. Kusniati, "The Insertion of Local Wisdom Intructional Material of Bahasa Indonesia for 10 th Grade Students in Senior High School," Journal of Education and Practice, vol. 6, No. 33, 2015.

[7] U. Fajarini, "Peranan Kearifan Lokal dalam Pendidikan Karakter, Sosio Didaktika," vol. 1, No. 2 Des 2014.

[8] Koentjaraningrat, Kebudayaan, Mentalitet dan Pembangunan, Jakarta: Gramedia, 1974.

[9] U.S. Winataputra, and D. Budimansyah, Pendidikan Kewarganegaraan dalam Persfektif Internasional: Konteks, Landasan, Bahan ajar dan Kultur kelas, Bandung: Widya Aksara Press, 2012.

[10] U.S. Winataputra, Pengembangan "civic culture" dalam Pembelajaran Pendidikan Kewarganegaraan diSekolah Dasar dan Menengah Atas, Jakarta : PPs-Universitas Terbuka, 2006

[11] H. Annette, "Introduction to Civic Cultures," Reprints and permission: sagepub.com/journalsPermissions.nav SAGE, Television \& New Media, vol 14, No. 1, pp. 3-4, 2013.

[12] J.P. Spradley, Metode Etnografi, Yogyakarta: Tiara Wacana, 2006.

[13] M.B Miles, and M. Huberman, Analisis Data Kualitatif: Buku Sumber, 1992.

[14] K. Kongprasertamorn, "Local wisdom environmental protection and community development: the clam farmers in Tambon Bangkhunsai, Phetchaburi Province, Thailand," Manusya: Journal of Humanities, vol. 10, No. 1, pp. 1-10, 2007.

[15] N.A. Rashid, "Nilai Kesantuan dalam Konteks Sosio budaya Masyarakat Melayu," Jurnal Pengajian Melayu, 2005.

[16] A. Nata, Sosiologi Pendidikan Islam, Jakarta: Rajawali Press, 2014. 